\title{
TERRITORIAL ANALYSIS OF POLITICAL PREFERENCES OF THE POPULATION (BASED ON THE LOWER VOLGA MESOREGION OF THE SOUTHERN FEDERAL DISTRICT OF RUSSIA)
}

\author{
Vladimir V. Fesenko \\ Volgograd State University, Volgograd, Russian Federation \\ Liliya V. Detochenko \\ Volgograd State Socio-Pedagogical University, Volgograd, Russian Federation
}

\begin{abstract}
Introduction. In modern Russian society, understanding of elections as an important component of the country's social and political life in the context of differences in political orientations of the population is increasingly affirmed. This statement makes it possible to consider the geography of elections both in individual regions and in the country as a whole, as well as to conduct a deep historical analysis to better understand the current political processes in the country. Methods. It seems most important to consider this problem in the context of the federal elections for the post of President of the Russian Federation using the statistical method. The comparative and cartographic methods contribute to a better understanding of geographical features of political preferences of the electorate. Analysis. The study shows that the development of any process, including political one, is seriously influenced by the regional specificity of the territory, affecting all of its spheres. In this regard, it is necessary to single out the reasons for the nature of changes in electoral preferences of voters in the territory under study. Results. The authors trace the dynamics of the electoral activity of the population of the Lower Volga mesoregion in the presidential elections. The researchers reveal the change of electoral preferences of voters for the period under review. The paper presents the territorial analysis of the political preferences of the population identified in the process of federal elections; marks their multidirectional nature. The authors identify the main reasons for the changes in electoral preferences of voters in the Lower Volga mesoregion at the presidential elections.

Key words: elections, mesoregion, political processes, political parties, political system of the country, federal elections, electoral behavior.

Citation. Fesenko V.V., Detochenko L.V. Territorial Analysis of Political Preferences of the Population (Based on the Lower Volga Mesoregion of the Southern Federal District of Russia). Vestnik Volgogradskogo gosudarstvennogo universiteta. Seriya 4. Istoriya. Regionovedenie. Mezhdunarodnye otnosheniya [Science Journal of Volgograd State University. History. Area Studies. International Relations], 2019, vol. 24, no. 5, pp. 172-192. (in Russian). DOI: https://doi.org/10.15688/jvolsu4.2019.5.13
\end{abstract}

\section{ТЕРРИТОРИАЛЬНЫЙ АНАЛИЗ ПОЛИТИЧЕСКИХ ПРЕДПОЧТЕНИЙ НАСЕЛЕНИЯ (НА ПРИМЕРЕ НИЖНЕВОЛЖСКОГО МЕЗОРЕГИОНА ЮЖНОГО ФЕДЕРАЛЬНОГО ОКРУГА РОССИИ)}

\author{
Владимир Владимирович Фесенко
}

Волгоградский государственный университет, г. Волгоград, Российская Федерация

Лилия Валерьяновна Деточенко

Волгоградский государственный социально-педагогический университет, г. Волгоград, Российская Федерация 
Аннотация. Введение. В современном российском обществе все более утверждается понимание выборов как важной составляющей части общественно-политической жизни страны в контексте различий в политических ориентациях населения. Это утверждение позволяет рассмотреть географию выборов как в отдельно взятых регионах, так и по стране в целом, а также провести глубокий исторический анализ для более полного понимания происходящих политических процессов в стране. Memodbl. Представляется наиболее важным рассмотреть данную проблему в контексте федеральных выборов на должность Президента Российской Федерации с применением статистического метода. Сравнительный и картографический методы способствуют лучшему пониманию географических особенностей политических предпочтений электората. Анализ. Исследование показало, что на развитие любых процессов, в том числе политических, серьезное влияние оказывает региональная специфика территории, затрагивающая все ее сферы. В этой связи необходимо выделить причины, обусловливающие характер изменений электоральных предпочтений избирателей рассматриваемой территории. Результаты. Прослежена динамика избирательной активности населения Нижневолжского мезорегиона на выборах Президента страны. Выявлена смена электоральных предпочтений избирателей за рассматриваемый период. Проведен территориальный анализ политических предпочтений населения, выявленных в процессе федеральных выборов; отмечен их разнонаправленный характер. Определены основные причины изменений электоральных предпочтений избирателей Нижневолжского мезорегиона на президентских выборах. В.В. Фесенко рассмотрел результаты президентских выборов, выявил смену электоральных предпочтений и определил основные причины их изменений. Л.В. Деточенко основное внимание уделила анализу активности электората и территориальных особенностей политических предпочтений избирателей.

Ключевые слова: выборы, мезорегион, политические процессы, политические партии, политическая система страны, федеральные выборы, электоральное поведение.

Цитирование. Фесенко В. В., Деточенко Л. В. Территориальный анализ политических предпочтений населения (на примере Нижневолжского мезорегиона Южного федерального округа России) // Вестник Волгоградского государственного университета. Серия 4, История. Регионоведение. Международные отношения. - 2019. - Т. 24, № 5. - С. 172-192. - DOI: https://doi.org/10.15688/jvolsu4.2019.5.13

Введение. Современный этап развития политологии как комплексной науки о различных сторонах политической жизни общества связан с совершенствованием используемых методов, все более носящих пограничный (междисциплинарный) характер. Если говорить о комплексных исследованиях регионов, то, как отмечает Р.Ф. Туровский, - речь идет о «степени “географичности” политологии, то есть учета в политологических исследованиях территориальности политических явлений» [8, с. 7]. Отсюда возникла потребность в политической географии, исследующей это их свойство существующей на стыке политологии и географии, относящейся к системе политических наук и использующей в своих исследованиях географический метод.

Одним из развивающихся направлений политической географии, вызывающих повышенный интерес, в настоящее время является электоральная география. Она изучает довольно актуальные проблемы для современного российского общества, а именно - политические процессы в пространстве, политикогеографические особенности государства с точки зрения поведения электората. Настоя- щая работа представляет собой попытку исследования характера этих процессов на региональном уровне.

Прежде всего необходимо уточнить некоторые определения. Во-первых, выборы являются важным компонентом общественной и политической жизни страны и формой политического участия граждан РФ в государственной жизни. Они представляют собой один из наиболее важных институтов народовластия и способов реализации политической субъективности граждан. В первую очередь они важны в реализации конституционного права граждан, тем самым оказывая влияние на формирование политической структуры власти. Федеральные выборы - в первую очередь выборы Президента РФ - имеют первостепенное значение, отличаются высокой электоральной активностью избирателей и воспринимаются ими как наиболее значимые, так как они предполагают избрание высшего должностного лица государства, который является гарантом основного Закона страны, прав и свобод человека и гражданина, а также его руководящих органов власти. Они осуществляются непосредственно гражданами на основе 
федеральных законов: «О выборах Президента РФ», «О выборах депутатов Государственной Думы» и иных федеральных государственных органов, предусмотренных Конституцией РФ. Исход данных выборов влияет на ход политических событий как в отдельных субъектах РФ, так и в стране в целом. От результатов данных выборов зависит будущее страны на международной арене, а также экономическое, политическое, социальное и культурное развитие страны. Поэтому изучение электорального поведения избирателей в федеральных выборах позволяет проследить географию выборов и ее изменения, что является весьма актуальным для проведения историко-географического анализа и осмысления процессов дальнейшего развития российского общества.

Во-вторых, можно сказать, что современной российской политической системе как механизму организации и реализации политической деятельности присущи демократические принципы, которые предполагают расширение политического участия граждан, развитие многопартийности и становление партий иного типа. В целом становление такой системы меняет отношения государства и личности, где государство призвано гарантировать свободу и демократическую жизнь человека, а главным элементом политической системы демократического государства выступает человек как политический субъект.

B-третьих, политические партии являются существенным элементом политической системы и общественно-политической жизни страны. Они выступают носителями конкурирующих друг с другом политических курсов, служат выразителями интересов, потребностей и целей определенных социальных групп, связующим звеном между гражданским обществом и государством. Через партии и избирательные системы происходит формализация участия граждан в политической жизни. Партии принимают активное участие в функционировании механизма политической власти или оказывают опосредованное влияние на него. Важной чертой деятельности партий является их идеологическое воздействие на население, а также значительная роль в формировании политического сознания и культуры.
Статья построена следующим образом. Сначала рассматриваются результаты федеральных выборов на должность Президента Российской Федерации за взятый временной промежуток. Далее анализируется характер изменений предпочтений электората на территории рассматриваемого мезорегиона и определяются основные причины, вызвавшие их. Затем в заключении содержатся основные выводы о том, как поддержка избирателей может оказывать влияние на формирование политической структуры территориальной власти.

Методы и материалы. Одним из основных методов, используемых в настоящем исследовании, является изучение статистических материалов центральной избирательной комиссии Российской Федерации, а также избирательных комиссий рассматриваемых регионов. На основе использования статистического метода была представлена картина динамики явки избирателей Нижневолжского мезорегиона Южного федерального округа на президентских выборах 1996-2018 гг., а также результаты выборов по рассматриваемым регионам. Сравнительный метод позволил выявить сходство и различия в политических предпочтениях электората Нижневолжского мезорегиона за исследуемый период. Использование картографического метода способствовало лучшему пониманию конфигурации электорального поведения избирателей, изменений предпочтений электората регионов на президентских выборах. На основе методов анализа и синтеза информации были представлены географические особенности политических предпочтений населения Нижневолжского мезорегиона Южного федерального округа России.

Анализ. Авторская позиция выбора Нижневолжского мезорегиона Южного федерального округа, в состав которого входят Астраханская и Волгоградская области, а также Республика Калмыкия, в качестве территориального объекта исследования обусловлена следующими обстоятельствами. Во-первых, в основу экономико-географического районирования территории СССР 1963 г. было положено единство экономического районирования, административно-территориального деления и национального устройства. Выше- 
указанные субъекты РСФСР, а затем и РФ, стали относиться к Поволжскому экономическому району, и Волгоград фактически выполнял функции центра Нижнего Поволжья до образования федеральных округов. Но из-за значительной протяженности Поволжского экономического района вдоль реки Волги промышленно-сельскохозяйственный комплекс на севере района очень сильно отличался от комплекса, сложившегося на юге территории. И по своим экономико-географическим связям Нижнее Поволжье всегда больше тяготело к Югу России. Во-вторых, Юг России занимает особое место в евразийском пространстве страны. Этот макрорегион имеет ключевое значение для сохранения целостности Российской Федерации и успешной реализации стратегии развития России до 2020 года. Юг России, будучи по своей сути, по мнению А.Г. Дружинина, «геоэтнокультурным образованием», является самостоятельным макрорегионом в едином социально-экономическом пространстве современной России, обладающим воспроизводственной целостностью и являющимся непосредственным итогом пространственного развития русской цивилизации» [5, с. 23]. Нижнее Поволжье в этой связи является полиэтническим и поликонфессиональным мезорегионом, на территории которого проживают различные этносы, имеющие свои традиции жизнедеятельности. Однако базовый набор этих традиционных ценностей таков, что - и с этой точкой зрения следует согласиться - «...несмотря на наличие ряда негативных факторов, в том числе и процессы вестернизации, ...оказывающих существенное воздействие на формирование ценностно-смысловых установок и стереотипов политического мышления... традиционные духовно-нравственные ценности продолжают выступать в качестве значимых социальных регуляторов поведения» [6, с. 192]. В-третьих, не потеряла актуальности активно проводившаяся в первые 10-12 лет XXI в. дискуссия о реформировании административнотерриториального деления территории России, в том числе о создании на основе регионов, составляющих единое пространство Нижнего Поволжья, отдельного субъекта мезоуровня Нижневолжского края. И, наконец, в-четвертых, данный мезорегион, на наш взгляд, представ- ляется интересным для анализа потому, что он всегда, по мнению отечественных политологов, считался «красным поясом» России.

Для того чтобы проследить, как менялась электоральная картина в Нижневолжском мезорегионе Южного федерального округа и предпочтения избирателей, необходимо проанализировать президентские выборы за последние 22 года. Динамика явки избирателей за этот период времени представлена на рисунке 1.

Президентские выборы 1996 г. в Волгоградской области отмечались высокой явкой избирателей (72,2 \%), которая была выше, чем по России (69,81 \%). Выборы проходили в 2 тура. В результате голосования 16 июня 1996 г. предпочтения избирателей в первом туре разделились. За представителя демократических сил Б.Н. Ельцина проголосовало $28,59 \%$ участвовавших в выборах, Г.А. Зюганова от коммунистической партии Российской Федерации («КПРФ») поддержало 40,04 \% избирателей, А.И. Лебедя от общественного объединения «Конгресс русских общин» («КРО») - 13,65 \% электората, В.В. Жириновского от либерально-демократической партии России («ЛДПР») - 6,55 \%, Г.А. Явлинского от партии «Яблоко» - 6,43\%, а против всех проголосовало 4,83 \% [2].

Вышеуказанные результаты, на наш взгляд, наглядно продемонстрировали широкий диапазон плюрализма мнений избирателей региона - от фактического отрицания советской политической системы и ориентации на демократические ценности в целом в их западной интерпретации (Б.Н. Ельцин) до возрождения с элементами модернизации советской власти (Г.А. Зюганов). Примерно поровну избиратели поддержали представителей партий демократического направления: партии, придерживающейся идей либерализма, демократии и в экономической сфере - теории смешанной экономики (В.В. Жириновский), и представителя социально-либеральной партии, отдающей предпочтение европейской модели либерализма с учетом российской специфики (Г.А. Явлинский). В целом же совокупный показатель всех представителей демократического направления превысил результат кандидата от «КПРФ» всего лишь на 1,53 \%. Совокупный третий результат показал предста- 
витель общественного объединения, придерживающегося федералистской идеологии (А.И. Лебедь).

Во втором туре борьба шла между лидером коммунистов и действующим Президентом России - Б.Н. Ельциным. В результате голосования Г.А. Зюганова поддержало $50,48 \%$, а за Б.Н. Ельцина проголосовало $44,21 \%$, против обоих - 4,55 \%. Дополнительные голоса победитель получил, на наш взгляд, за счет избирателей, голосовавших в первом туре за кандидата от «КРО», а также - за представителя партии «Яблоко», как следствие негативной реакции на первые итоги российских реформ. Таким образом, Волгоградская область отдала предпочтение Г.А. Зюганову. Однако можно отметить, что в области представитель демократических сил Б.Н. Ельцин одержал победу с небольшим перевесом голосов в Котовском районе $(48,21 \%)$, в г. Волжском $(46,96 \%)$ и г. Волгограде $(57,19 \%)$ (см. рис. 2,3$)$.

Явка избирателей на президентских выборах в Астраханской области в 1996 г. составила $69,37 \%$, что несколько ниже среднего по стране. В результате голосования Б.Н. Ельцина поддержало 29,48 \%, Г.А. Зюганова $-36,49 \%$, А.И. Лебедя - 16,12\%, В.В. Жириновского - 7,15 \%, Г.А. Явлинского - 6,43\%, а против всех проголосовало $4,83 \%$ электората. Во втором туре Г.А. Зюганова поддержало 47,79 \%, а за Б.Н. Ельцина проголосовало $46,85 \%$, против обоих 4,42 \% проголосовавших избирателей. Таким образом, Астраханская область, также как и Волгоградская, отдала предпочтение Г.А. Зюганову. При этом Б.Н. Ельцин одержал победу в городах Астрахань $(56,25 \%$ ) и Знаменск $(61,14 \%)$. В целом результаты выборов по Астраханской области корреспондируются с итогами выборов по Волгоградской области [1] (см. рис. 4, 5).

Самая высокая явка избирателей на президентских выборах в 1996 г. в Нижневолжском мезорегионе ЮФО была отмечена по Республике Калмыкия - 75,77 \%. В результате голосования в первом туре за Б.Н. Ельцина проголосовало 58,49 \%, Г.А. Зюганова $25,72 \%$, А.И. Лебедя $-5,42 \%$, В.В. Жириновского - 3,57 \%, Г.А. Явлинского - 2,50 \%, а против всех - 0,91\% электората. Отметим, что лидер коммунистов одержал победу в Городовиковском и Яшалтинском районах. Во втором туре Г.А. Зюганова поддержало $26,71 \%$, а за Б.Н. Ельцина проголосовало $70,27 \%$, против обоих - 1,98 \% проголосовавших избирателей [3]. При этом Б.Н. Ельцин одержал победу по всем территориальным избирательным комиссиям региона. В целом достаточно убедительная победа Б.Н. Ельцина, заложенная уже в первом туре голосования, обусловлена, на наш взгляд, мобилизацией административного ресурса на основе имеющейся позиции местных властей республики и подконтрольностью местного электората. Таким образом, Республика Калмыкия, в отличие от своих соседей по мезорегиону, поддержала представителя демократических сил Б.Н. Ельцина (см. рис. 6,7 ).

Активность электората на выборах Президента РФ 26 марта 2000 г. в Нижневолжском мезорегионе была достаточно высока: так, в Волгоградской области проголосовало 68,4 \% избирателей, Астраханской области 68,97 \%, Республике Калмыкия - 69,78 \%. Основными кандидатами на пост Президента России были В.В. Путин и Г.А. Зюганов. Данные выборов показали изменения в предпочтениях электората Волгоградской и Астраханской областей, а именно, большинство избирателей отдали свои голоса за В.В. Путина 53,50 и $61,63 \%$ соответственно. В Республике Калмыкия за него проголосовали 56,25 \% избирателей. Однако симпатии к левым остались на высоком уровне: в Волгоградской области и Республике Калмыкия за Г.А. Зюганова проголосовало гораздо больше, чем в среднем по стране $(33,94 \%$ и 32,21 \% против $29,24 \%$ соответственно). В Астраханской области этот показатель равен 26,94 \%.

В Волгоградской области В.В. Путин одержал победу в 4 городах (Волгоград, Волжский, Камышин, Фролово) и 26 сельских районах области. Г.А. Зюганов одержал победу в двух городах (Михайловка, Урюпинск) и в 7 сельских районах области (Еланский, Киквидзенский, Кумылженский, Николаевский, Новоаннинский, Палласовский, Старополтавский) [2]. В Астраханской области и Республике Калмыкия В.В. Путин одержал победу по всем территориальным избирательным комиссиям этих регионов $[1 ; 3]$ (см. рис. 8,9 ). 
Президентские выборы 14 марта 2004 г. в Волгоградской области отличились от предыдущих невысокой электоральной активностью избирателей. Явка составила $55,7 \%$, что почти на $13 \%$ ниже, чем в 2000 году. Итоги прошедших выборов показали лидирующую позицию В.В. Путина, за которого проголосовало 63,03 \% электората области. Данная цифра на $10 \%$ больше, чем в 2000 г., и почти в 2 раза больше, чем за всех остальных кандидатов вместе взятых. Наибольшую поддержку электората он получил в западных регионах области (Алексеевский - 69,77 $\%$, Серафимовичский $-65,22 \%)$ и в более южных регионах - это Городищенский $(67,54$ $\%)$, Калачевский $(70,04 \%)$ районы. Среди восточных регионов Волгоградской области наибольший процент голосов Путин получил в Среднеахтубинском районе $(65,12 \%)$, а среди южных - в Котельниковском районе $(64,82 \%)$ [2].

Высокий процент голосов за В.В. Путина говорит о том, что избиратели были довольны его работой на первом сроке правления на месте главы государства. Высокая поддержка представителя демократических сил также объясняется ясностью его программной платформы, принятием его политического и экономического курса развития страны, в котором электорат видит предпосылки демократии, надежду на стабильность, безопасность в стране и уверенность в будущем.

Второе место на этих выборах в области занял представитель партии «КПРФ» Н.М. Харитонов, который получил 21,95 \% голосов избирателей области. Данный результат на 7,3 \% меньше, чем на предыдущих президентских выборах у Г.А. Зюганова. Наибольший процент голосов он получил в западных регионах области (Кумылженский $36,39 \%$, Суровикинский $-34,82 \%$ и на севере области - это Еланский $(35,65 \%)$, Даниловский $(35,18 \%)$, Котовский $(33,09 \%)$ районы. Меньше всего голосов кандидат набрал в Городищенском $(17,71 \%)$ и Калачевском $(18,47 \%)$ районах области. Согласно данным избиркома, остальные кандидаты на этих выборах не смогли набрать высоких результатов, что можно объяснить и неясностью их позиций, и другими электоральными предпочтениями избирателей [2].
Президентские выборы 14 марта 2004 г. в Астраханской области отличились активностью избирателей. Явка составила 59,32 \%. Большинство электората области поддержало политический курс В.В. Путина, который на этих выборов занял первое место с результатом 66,08 \% голосов по области. Наибольший процент голосов за его кандидатуру отдали избиратели восточной части области Володарский $(74,43 \%)$, Красноярский (70,46 \%), Приволжский $(71,26 \%)$ районы. В административном центре области за Путина проголосовало 66,7 \% избирателей. Наибольшую электоральную поддержку ему оказали жители Трусовского района г. Астрахани $(67,36 \%)$. Наименьшее количество голосов он получил на севере области - в Черноярском $(54,50 \%)$ и Ахтубинском $(54,12 \%)$ районах.

Среди других кандидатов можно отметить Н.М. Харитонова, который набрал 18,28 \% по области и оказался на втором месте. Наибольшее количество голосов избирателей он получил на севере области, а именно, в Ахтубинском (31,48 \%) и Черноярском $(31,88 \%)$ районах, а наименьшее - на востоке области - Володарский $(17,06 \%)$ и Красноярский $(17,87 \%)$ районы, и в городе Знаменске за него проголосовало 11,76 \% избирателей. В административном центре наибольшее количество голосов он набрал в Трусовском районе $(15,51 \%)$. Остальные кандидаты набрали в сумме $11,08 \%$ [1].

Выборы Президента РФ 2004 г. в Республике Калмыкия проходили активно. Электоральная активность населения составила $71,52 \%$. Такая высокая явка в данном субъекте РФ обусловлена применением административного ресурса со стороны руководства. На этих выборах по данному субъекту РФ победу одержал В.В. Путин с результатом 79,23 \% голосов. Рекордное число голосов он набрал в Черноземельском районе $(90,02 \%)$ на востоке республики и в Целинном районе $(86,58 \%)$ на западе. Наименьшее количество голосов было отдано в Малодербетовском районе $(68,85$ \%). Н.М. Харитонов, выдвигавшийся от партии «КПРФ», стал на этих выбоpax вторым. Он набрал 11,13 \% голосов избирателей. Наибольшее количество голосов за него отдали жители севера республики - Городовиковский район $(19,86 \%)$, а на западе - 
Малодербетовский район (20,98 \%). Меньше всего голосов он получил в Черноземельском районе (4,93 \%). Согласно данным избиркома Республики Калмыкия, остальные кандидаты не смогли себя зарекомендовать на этих выборах: в целом за них было отдано 7,5 \% голосов избирателей [3].

Таким образом, президентские выборы 2004 г. на территории Нижневолжского мезорегиона проходили достаточно активно. Наибольшей активностью отличился электорат Республики Калмыкия. Это объясняется в первую очередь тем, что со стороны республиканского руководства в ходе выборов применялся административный ресурс, направленный на повышение явки.

Итоги выборов 2004 г. наглядно продемонстрировали, что «красный пояс» в лице коммунистов сдает свои позиции, так как электорат не видит перспектив проводимого ими курса. За них голосует в основном население, которое ностальгирует по советскому прошлому, тем самым партия «КПРФ» и ее лидер набирают значительный процент голосов на федеральных выборах. Наибольшую поддержку коммунистам оказывает электорат Волгоградской области, а за кандидатуру В.В. Путина - электорат Республики Калмыкия, где он набирает рекордное количество голосов избирателей.

Выборы Президента РФ 2 марта 2008 г. в Волгоградской области отличились большой электоральной активностью избирателей. Явка по области составила $64,8 \%$, что почти на 9,1\% выше, чем на выборах 2004 года. Наибольшей активностью выделились два крупных города области - это г. Волгоград и г. Волжский, явка в которых составила больше, чем в среднем по области. Это говорит о том, что населению области не все равно, каким будет будущее России, так как именно «в руках» Президента сосредоточены основные полномочия по ведению государственных и управленческих дел страны. Именно выбранный политический курс определяет будущее развитие и место России на международной арене.

Первое место на этих выборах занял представитель партии «Единая Россия», идеология которой основывается на сохранении суверенитета страны и повышении качества жизни россиян, Д.А. Медведев, набравший
62,27 \% голосов. Наибольшую поддержку электората он получил на северо-западе области в Алексеевском $(73,72 \%)$ и Урюпинском $(65,99 \%)$ районах. Среди северных районов области наибольшее доверие избиратели оказали ему в Камышинском районе $(67,79 \%$ ), на востоке области - в Палласовском районе $(65,71 \%)$, а на юге - Котельниковском районе $(66,09 \%)$. В г. Волгограде Д.А. Медведев набрал $62,16 \%$, большую поддержку избирателей он получил в Краснооктябрьском районе $(63,78 \%)$. Такой высокий процент голосов за данного кандидата говорит о том, что избиратели принимают и поддерживают продолжение курса В.В. Путина, который направлен на развитие России и Волгоградской области в частности.

Второе место на выборах 2008 г. занял представитель «КПРФ» - Г.А. Зюганов, его результат составил $24,25 \%$. Наибольшее количество голосов электората он набрал в северных районах области - это Еланский $(32,79 \%)$, Котовский $(32,82 \%)$ районы, г. Урюпинск $(32,06 \%)$ и г. Михайловка $(31,81 \%)$. 11,37 \% избирателей поддержали представителя «ЛДПР» В.В. Жириновского [2].

Выборы Президента РФ 2008 г. в Астраханской области отличились высокой явкой, которая составила 66,9 \%. Рекордный результат набрал Д.А. Медведев с результатом 75,28 \% по области, а по административному центру $-84,16 \%$. Самый высокий результат Медведев набрал в Советском районе г. Астрахани (87,76 \%). У Г.А. Зюганова, согласно данным избиркома, результат по области составил 17,29 \%. Наибольший процент голосов за него отдал электорат Ахтубинского $(32,98 \%)$ и Черноярского $(29,91 \%)$ районов севера области. Самый низкий результат в Советском районе г. Астрахани - 8,54\%. Другие кандидаты не зарекомендовали себя на выборах. Так, результат В.В. Жириновского составил 5,80\% [1].

Выборы Президента РФ 2008 г. в Республике Калмыкия проходили менее активно, чем в 2004 году. Явка составила $62,05 \%$, что на 9,47 \% меньше по сравнению с прошлыми выборами. Наибольшую поддержку электората получил Д.А. Медведев, который продолжает курс своего наставника в лице Путина, его результат составил 71,56 \% голосов 
избирателей. Большее количество голосов за него было отдано в Черноземельском $(94,85 \%)$ и Яшкульском $(81,47 \%)$ районах, расположенных в восточной части Республики Калмыкия. Наименьшую поддержку ему оказали жители Малодербетовского района 60,72 \% голосов. Наибольшее количество голосов коммунист по-прежнему получил в Городовиковском $(29,03 \%)$ и Малодербетовском $(32,48 \%)$ районах. Результат Г.А. Зюганова по республике составил 22,30 \% голосов, что в 2 раза выше, чем на предыдущих выборах. Кандидата от партии «ЛДПР» поддержало всего 4,14 \% избирателей [3].

В целом выборы 2008 г. проходили достаточно активно по всему Нижневолжскому региону РФ, что свидетельствует о значимости данных выборов, исход которых определяет будущее развитие страны, в первую очередь на международной арене.

Итоги выборов 2004 и 2008 гг. показали, что на политической арене, с одной стороны, появились явные лидеры в лице В.В. Путина и его приемника Д.А. Медведева. С другой очевидна явная поддержка со стороны электората и их доминирование над другими кандидатами, что можно объяснить доверием и надеждой избирателей на становление государства с демократическим политическим режимом, основанном на признании народа в качестве источника власти.

Президентские выборы 2012 г. в Волгоградской области отличились меньшей активностью избирателей по сравнению с выборами 2008 г. почти на $1 \%$. Явка по области составила $63,85 \%$. Наибольший процент голосов на этих выборах набрал В.В. Путин, его результат составил $63,41 \%$. Вторым на этих выборах по-прежнему стал кандидат из партии «КПРФ» - Г.А. Зюганов - с результатом $18,85 \%$ голосов [2].

Проанализировав результаты выборов по районам Волгоградской области и ее крупным городам, можно отметить, что электоральные предпочтения выборов складывались неровно. Так, например, большее количество голосов за В.В. Путина отдали жители северных и северо-западных районов области: это Урюпинский (69,48 \%), Новониколаевский $(69,73 \%$ ), Киквидзенский $(69,74 \%)$, Руднянский $(69,98 \%$ ) районы. Наибольшую поддержку электората в целом по области он получил в Алексеевском районе $(85 \%)$. На юге области большее количество голосов набрал в Котельниковском районе $(69,05 \%)$, а на востоке - в Николаевском районе $(69,10 \%)$. Меньше всего голосов В.В. Путин набрал в Котовском районе $(50,6 \%)$ и в г. Михайловка $(45,98 \%)$. Активным голосованием отличился г. Волгоград, в котором явка избирателей составила 61,28 \%. В Волгограде В.В. Путин набрал больше всех голосов в Дзержинском районе $(73,03 \%)$, а меньшее количество голосов - в Тракторозаводском районе $(55,2 \%)$.

За кандидата от партии «КПРФ» по области избиратели голосовали также неровно. Наибольший процент голосов лидер коммунистов получил в Котовском районе $(30,38 \%)$ и в городе Михайловка $(29,45 \%)$. Минимальный процент голосов он набрал в Алексеевском районе $(6,13 \%)$. Остальные кандидаты на этих выборах не отметились значительной поддержкой электората. Третье место занял В.В. Жириновский с результатом $6,86 \%$, М.Д. Прохоров оказался на четвертом месте $(5,56 \%)$, а С.М. Миронов - на последнем $(4,33 \%)[2]$.

Выборы главы государства 2012 г. в Астраханской области также не отличались высокой активностью избирателей. Явка составила $56,33 \%$, что почти на $11 \%$ ниже по сравнению с выборами 2008 года. По данным избиркома, наибольшее количество голосов было отдано за В.В. Путина $(68,76$ \%). Наибольшую поддержку по области ему оказал Приволжский район $-86,51 \%$, а в административном центре - Советский район с результатом 71,55 \% голосов. Второе место занял Г.А. Зюганов с результатом $15,64 \%$ голосов. Лучший результат он показал в Ахтубинском $(29,55 \%)$ и Черноярском (27,93\%) районах. Меньше всего голосов - в Приволжском районе $(6,43 \%)$. Другие кандидаты не отличились высокой поддержкой электората Астраханской области. За В.В. Жириновского проголосовало 5,07 \% избирателей, М.Д. Прохоров набрал 5,06 \% голосов и С.М. Миронов $4,30 \%$ голосов [1].

Самая низкая явка на выборах Президента РФ 2012 г. по мезорегиону была отмечена в Республике Калмыкия: она составила $52,77 \%$, что на 9,28 \% меньше, чем на выбо- 
рах 2008 года. Лидером на этих выборах стал В.В. Путин с результатом 70,30\% голосов. Лучший результат он показал в южных районах - Черноземельском $(88,35 \%)$ и Ики-Бурульском $(78,36 \%)$ районах, а на севере - в Октябрьском районе $(79,91 \%)$. Однако можно заметить, что его результаты значительно ниже, чем на выборах 2004 года. Второе место занял Г.А. Зюганов с результатом $17,51 \%$ голосов. Лучший результат он показал в Городовиковском $(26,59 \%)$ и Малодербетовском $(24,48 \%)$ районах, а худший - в Черноземельском районе $(7,38 \%)$. Более $2 \%$ избирателей проголосовали за В.В. Жириновского и С.М. Миронова, за кандидата М.Д. Прохорова $-6,04 \%$ голосов избирателей [3].

Выборы Президента Российской Федерации 2018 г. по регионам Нижнего Поволжья можно охарактеризовать следующими особенностями. Во-первых, более высокой электоральной активностью по сравнению с 2012 годом. Явка избирателей составила по Волгоградской и Астраханской областям и Республике Калмыкия 68,14; 60,42 и 69,65 \% соответственно, или в целом по мезорегиону$66,07 \%$. Однако этот показатель несколько ниже среднего по России (67,5 \%) [4].

Во-вторых, результаты выборов показали победу за явным преимуществом одного из кандидатов по всем трем рассматриваемым регионам. Им стал В.В. Путин, который баллотировался как самовыдвиженец. За него по Волгоградской и Астраханской областям и Республике Калмыкия проголосовало 77,55; 76,95 и 81,66 \% избирателей соответственно, что выше среднего показателя по стране $76,69 \%$. Эти результаты, в частности, показали, что «...у значительного числа избирателей есть устойчивые стереотипы (схематические представления) о персональных качествах успешных, эффективных политиков, которые можно рассматривать в качестве относительно стабильных ориентиров при оценке конкретных кандидатов в ходе избирательной кампании; ...среди таких персональных черт кандидатов перечисляются компетентность, честность, лидерские качества, ответственность (надежность) и отзывчивость (способность к сопереживанию)» $[7$, с. 123]. На наш взгляд, В.В. Путин в целом полностью соответствует вышеперечисленным критери- ям оценки персональных качеств успешных политиков.

На втором месте находился представитель «КПРФ» П.Н. Грудинин - 11,74; 14,40 и $11,66 \%$, или $12,60 \%$ в среднем по мезорегиону. Отметим, что этот показатель на 27,3 \% ниже аналогичного по выборам 2012 года. Столь резкое падение электоральной популярности партии коммунистов, на наш взгляд, можно объяснить, как минимум, двумя причинами: во-первых, очень высоким рейтингом кандидата В.В. Путина, во-вторых, выдвижением в качестве кандидата от «КПРФ» не бессменного лидера партии Г.А. Зюганова, а П.Н. Грудинина, предвыборная кампания которого сопровождалась рядом неблаговидных скандалов. Третье место занял В.В. Жириновский с результатами 5,$83 ; 4,35$ и $1,94 \%$ соответственно. Результаты голосования по остальным пяти кандидатам находятся в диапазоне статистической погрешности - от 0,36 до $1,51 \%$ [4].

В-третьих, В.В. Путин по Волгоградской области лучшие результаты показал по Алексеевскому $(87,13 \%)$ и Жирновскому $(84,39 \%)$ районам и городу Урюпинску $(84,29 \%)$. По Астраханской области наибольшее количество голосов он собрал по Трусовскому району административного центра - 90,70 \% и Приволжскому району - 88,93 \%. В Республике Калмыкия наибольшую поддержку ему обеспечили Черноземельский $(95,90 \%)$, Лаганский $(95,84 \%)$ и Ики-Бурульский $(91,30 \%)$ районы. П.Н. Грудинин наилучшие результаты по Волгоградской области показал по городу Михайловка $(18,17 \%)$ и Даниловскому району $(17,32 \%)$; по Астраханской области - в Красноярском районе $(27,51 \%)$, а по Республике Калмыкия - по административному центру $(14,99 \%)$ и Целинному $(13,45 \%)$, Яшкульскому $(13,06 \%)$ и Городовиковскому (12,95\%) районам [4].

Результаты. Как правило, на развитие любых процессов, в том числе политических, серьезное влияние оказывает региональная специфика территории, затрагивающая все ее сферы. В этой связи из нашего анализа можно сделать некоторые выводы, оговорив при этом, что они носят авторский характер и не претендуют на истину в последней инстанции. 
Во-первых, в целом выборы на должность Президента Российской Федерации за период 1996-2018 гг. в Нижневолжском мезорегионе Южного федерального округа отличались достаточной электоральной активностью населения: явка избирателей ни разу не опустилась ниже показателя в $50 \%$.

Во-вторых, начиная с выборов 2000 г. произошла смена электоральных предпочтений населения, что связано в первую очередь с надеждой населения на улучшение условий жизни. Электоральная картина Нижневолжского мезорегиона Южного федерального округа демонстрирует смену коммунистической политической системы демократической. Такая картина показывает, что произошла смена цветового фона, а именно «красный пояс», представленный левыми силами, сменился «синим поясом», который представляют правоцентристы (см. рис. 10).

В-третьих, внутрирегиональные изменения электоральных предпочтений исследуемого мезорегиона носили разнонаправленный характер. Так, электорат Волгоградской и Астраханской областей на выборах 1996 г. отдал предпочтения за кандидата от партии «КПРФ», тем самым поддерживая предлагаемый им курс по развитию страны. В Республике Калмыкия, наоборот, с серьезным отрывом победил представитель демократических сил. Результаты выборов 2000 г. позволяют говорить - хотя и в разной степени - о смене поддержки избирателей в пользу демократических сил, что в первую очередь можно объяснить, на наш взгляд, появлением в их рядах политика с сильными лидерскими качествами. Bсе последующие выборы в рассматриваемый период свидетельствуют о синхронизации вышеуказанного процесса в пользу представителей правоцентристов.

В-четвертых, электорат, поддерживающий политический курс кандидатов от «КПРФ», постепенно сужается. Одной из причин этого процесса является, на наш взгляд, то, что данный электорат в значительной мере состоит из ныне пожилых людей, живших в социалистический период и ностальгирующих по советскому прошлому. Но в настоящее время их число уменьшается за счет естественного процесса смертности этой части населения. Партия «Единая Россия», наоборот, расширяет свой круг избирателей, получая наибольшую поддержку электората в Республике Калмыкия и Астраханской области, наименьшую - в Волгоградской области (исключение в определенном смысле составляют результаты выборов 2018 года). Такая ситуация демонстрирует исчезновение так называемого «красного пояса». Однако по-прежнему «КПРФ» собирает большее количество голосов избирателей по рассматриваемому мезорегиону, даже несмотря на определенный провал, на наш взгляд, по результатам выборов 2018 года. Это говорит о том, что данная партия в настоящее время находится в кризисе, однако все еще не исчерпала свой политический потенциал и имеет в своем арсенале интересные предложения по развитию и функционированию общественно-политической жизни страны.

Отмеченная нами динамика электоральных предпочтений совпала с утверждением на политической арене Нижневолжского мезорегиона, начиная с выборов 2000-х гг., доминирующей партии - «Единой России». Полностью поддерживая политику избранных в данный период президентов и правительств страны, она завоевала большинство в региональных исполнительных и законодательных органах власти. Однако успех «Единой России» на данном этапе социально-экономического развития страны достигнут не только вследствие применения административного ресурса, но и благодаря авторитету В.В. Путина, который является фактическим лидером этой партии. Рост электората «партии власти» в Нижневолжском регионе ЮФО от выборов к выборам обусловлен тем, что избирателей в целом устраивает проводимый президентом политический курс, а также за счет тех людей, которые не имеют определенных политических убеждений и предпочитают сохранение имеющегося курса развития государства. 


\section{НАРОДЫ РОССИИ И ЕВРОПЫ: ИСТОРИЯ И ПОЛИТИКА}

\section{ПРИЛОЖЕНИЕ}

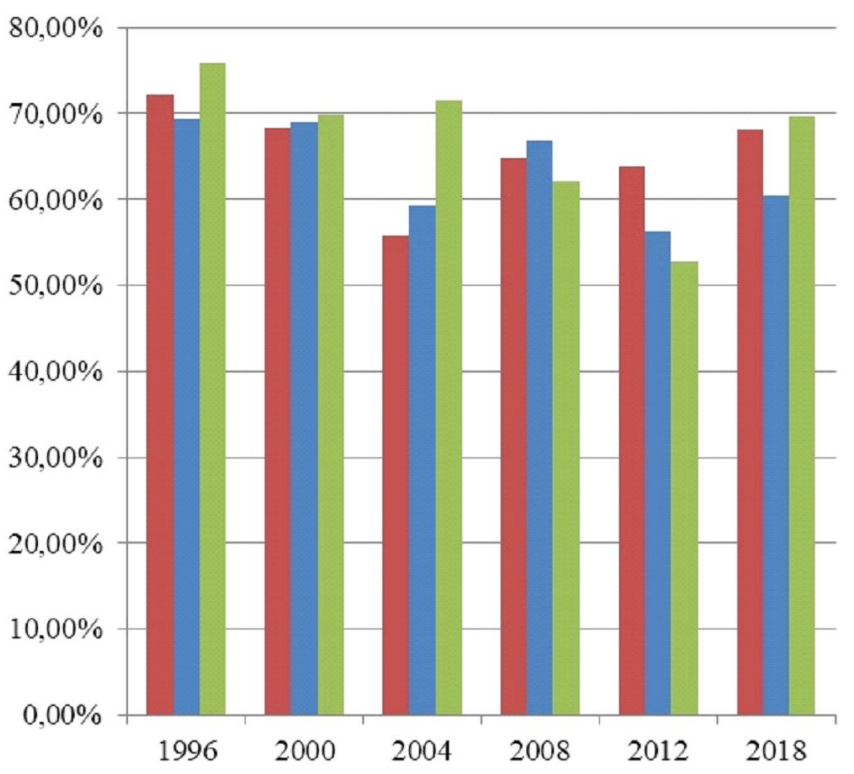

- Явка

избнрателей

Волгоградской

области

- Явка

нзбнрателей

Астраханской

области

- Явка

избнрателей

Республика

Калмыкия

Рис. 1. Динамика явки избирателей Нижневолжского региона ЮФО на президентских выборах 1996-2018 гг.

Fig. 1. Dynamics of voter turnout in the Lower Volga region of the Southern Federal District in presidential elections for 1996-2018

Примечание. Составлено авторами по: [1-4].

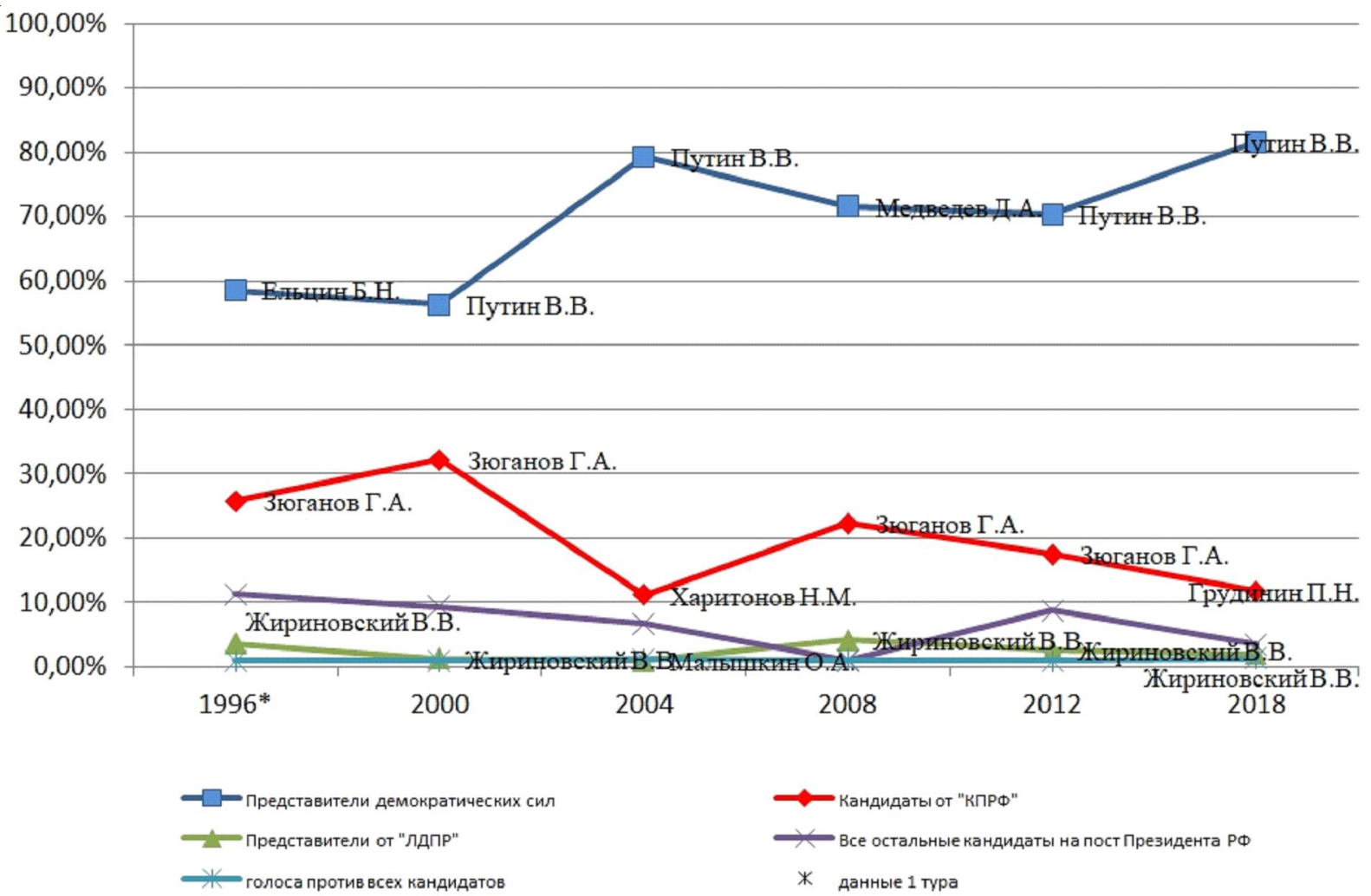

Рис. 2. Результаты выборов Президента РФ по Волгоградской области за 1996-2018 гг.

Fig. 2. Results of presidential elections in Volgograd region for 1996-2018

Примечание. Составлено авторами по: [2]. 
В.В. Фесенко, Л.В. Деточенко. Территориальный анализ политических предпочтений населения
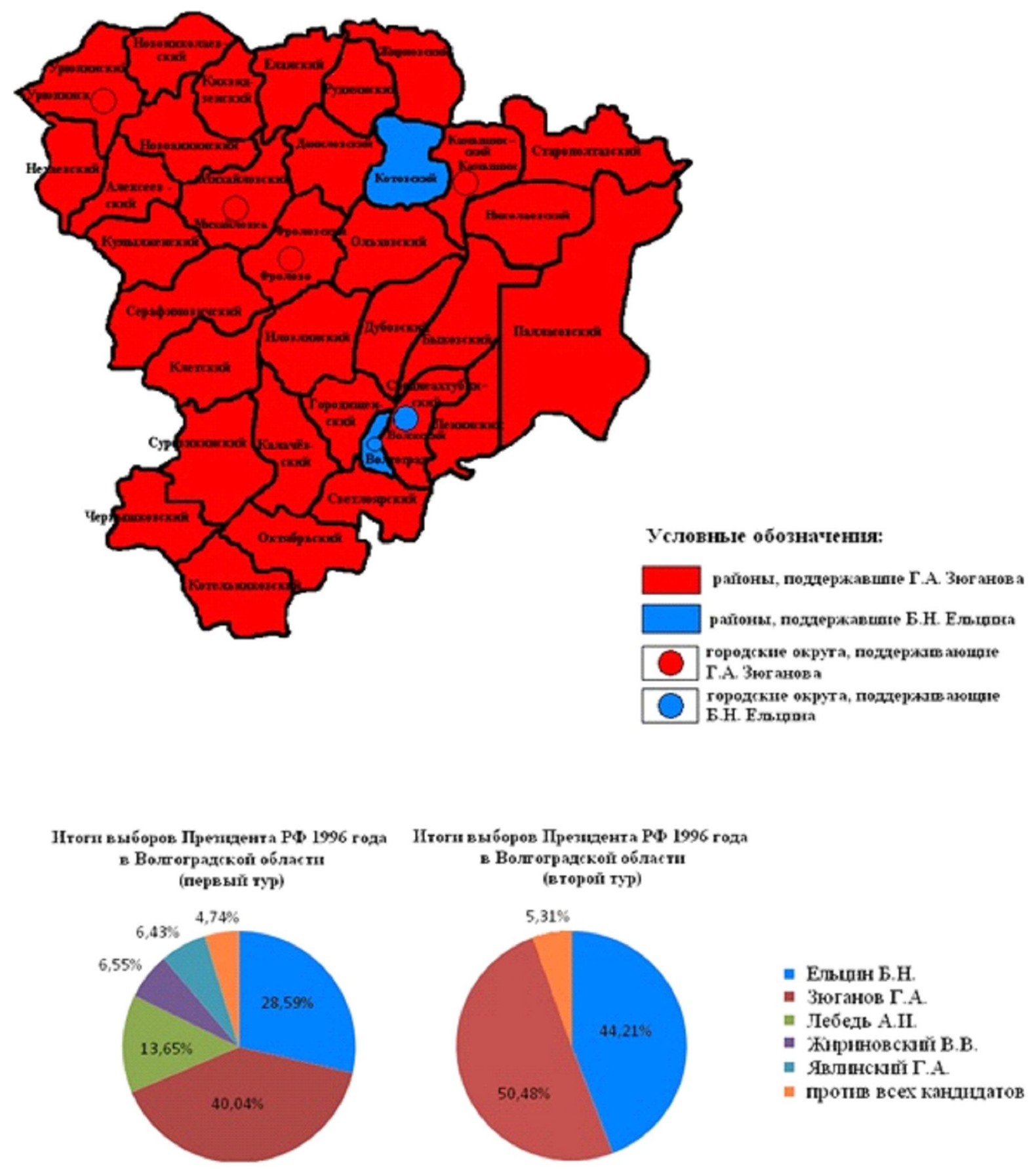

Рис. 3. Предпочтения электората Волгоградской области в выборах Президента РФ 1996 г.

Fig. 3. Preferences of the electorate of Volgograd region in the presidential elections of 1996 Примечание. Составлено авторами по: [2]. 


\section{НАРОДЫ РОССИИ И ЕВРОПЫ: ИСТОРИЯ И ПОЛИТИКА}

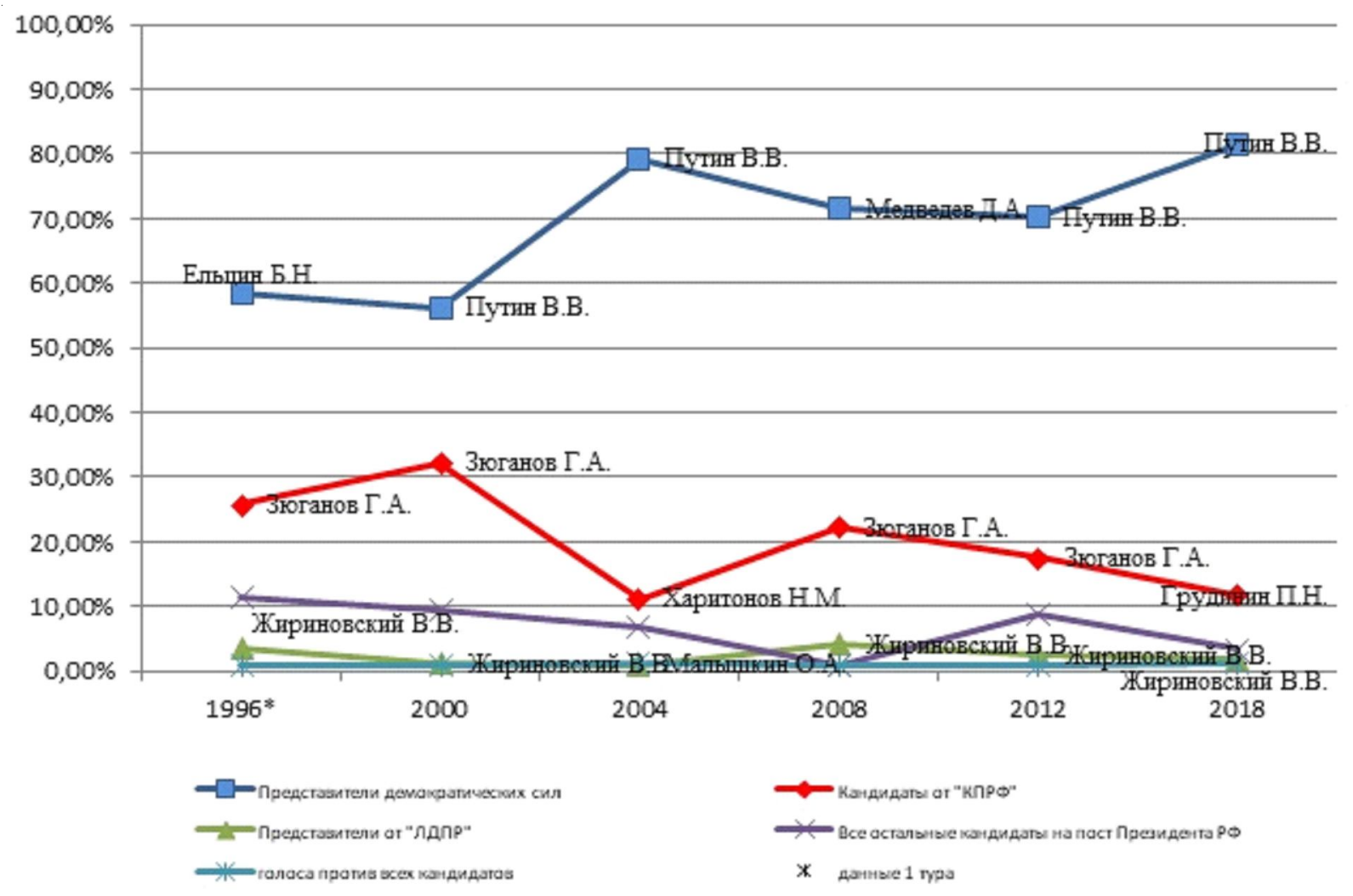

Рис. 4. Результаты выборов Президента РФ по Астраханской области за 1996-2018 гг.

Fig. 4. Results of presidential elections in Astrakhan region for 1996-2018

Примечание. Составлено авторами по: [1]. 
В.В. Фесенко, Л.В. Деточенко. Территориальный анализ политических предпочтений населения

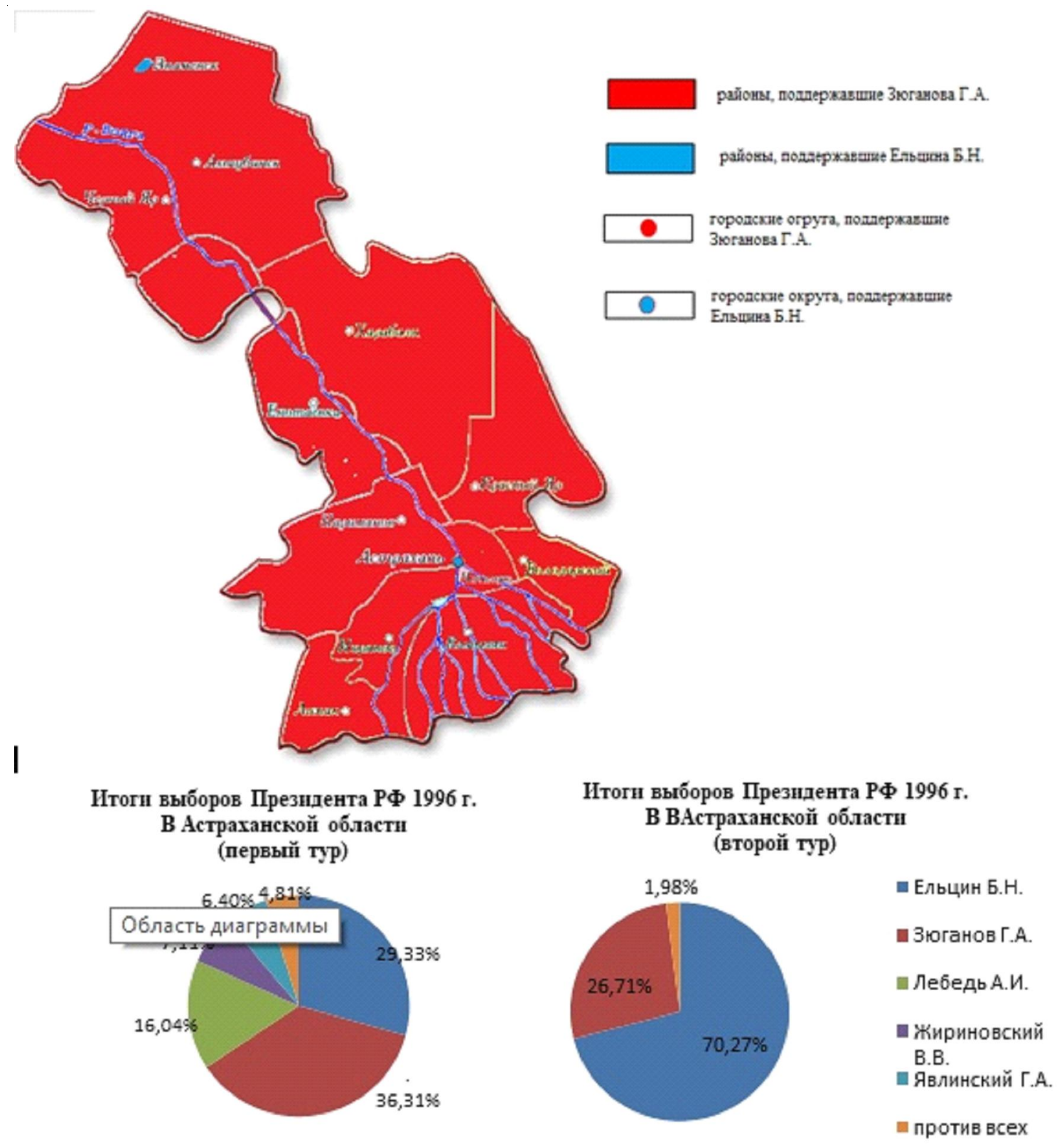

Рис. 5. Предпочтения электората Астраханской области в выборах Президента РФ 1996 г.

Fig. 5. Preferences of the electorate of Astrakhan region in the presidential elections of 1996 Примечание. Составлено авторами по: [1]. 


\section{НАРОДЫ РОССИИ И ЕВРОПЫ: ИСТОРИЯ И ПОЛИТИКА}

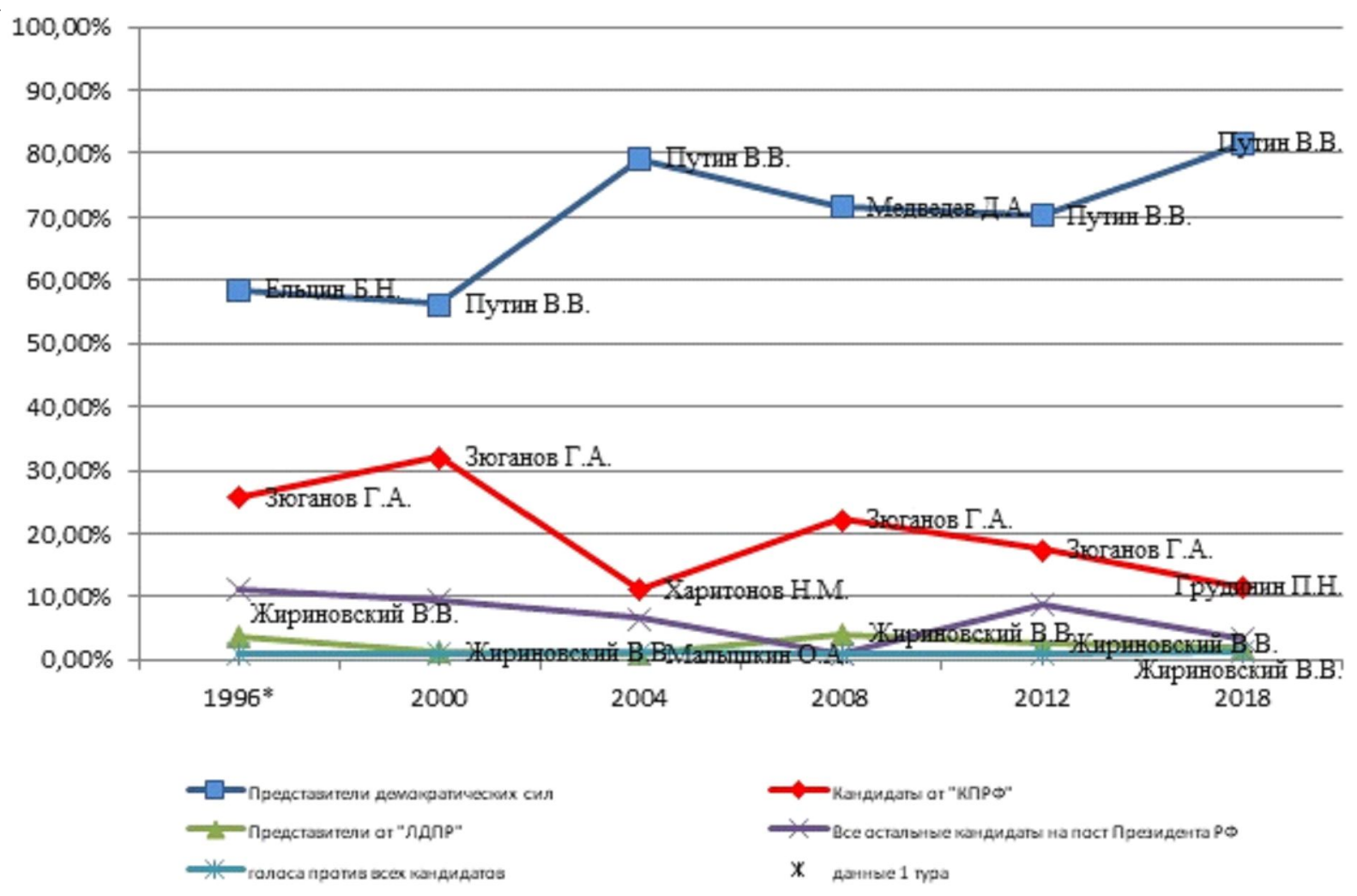

Рис. 6. Результаты выборов Президента РФ по Республике Калмыкия за 1996-2018 гг.

Fig. 6. Results of presidential elections in the Republic of Kalmykia for 1996-2018

Примечание. Составлено авторами по: [3] . 
В.В. Фесенко, Л.В. Деточенко. Территориальный анализ политических предпочтений населения

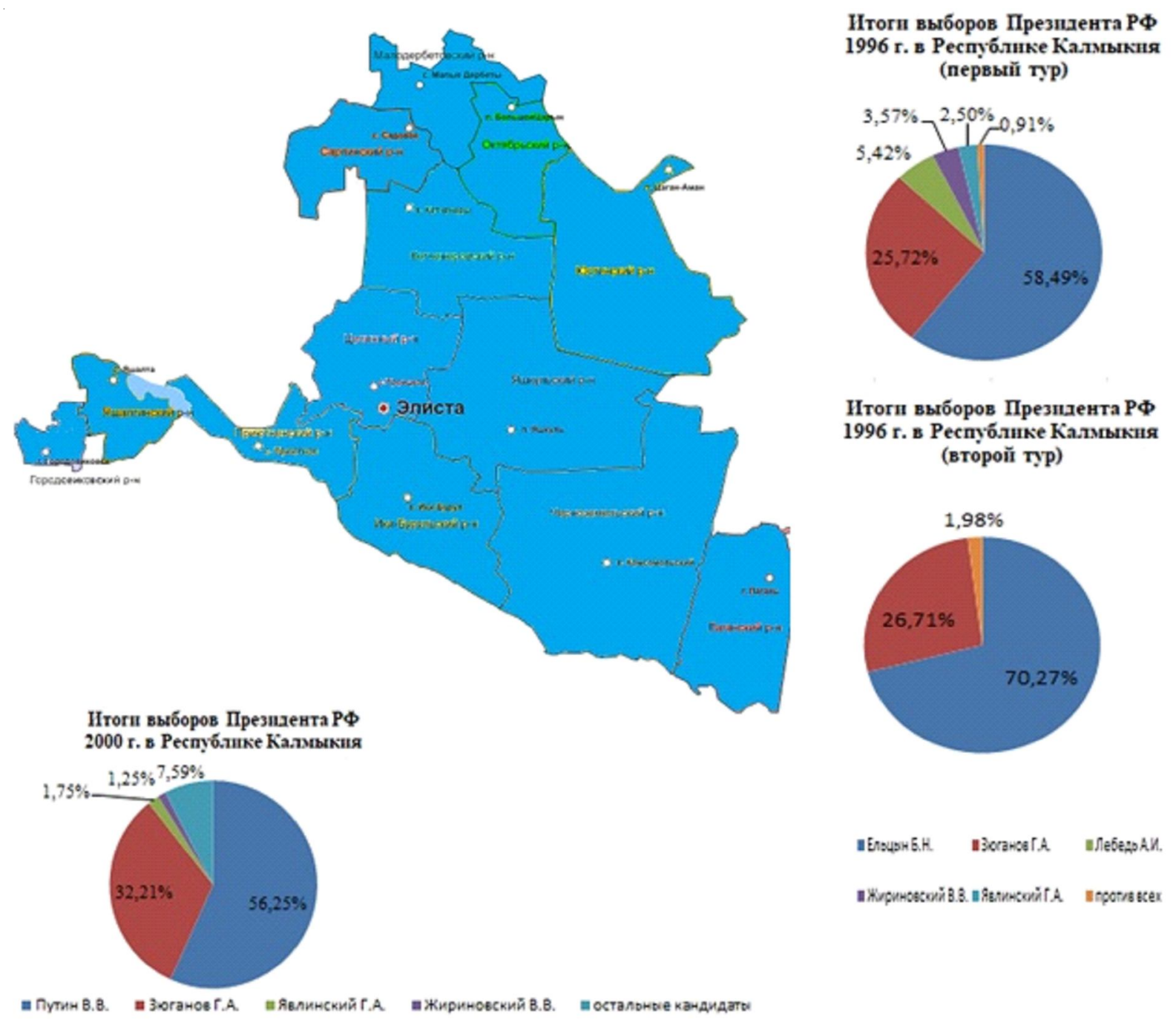

Рис. 7. Предпочтения электората Республики Калмыкия в выборах Президента РФ 1996 г. и 2000 г.

Fig. 7. Preferences of the electorate of the Republic of Kalmykia in the Presidential elections of 1996 and 2000

Примечание. Составлено авторами по: [3]. 


\section{НАРОДЫ РОССИИ И ЕВРОПЫ: ИСТОРИЯ И ПОЛИТИКА}

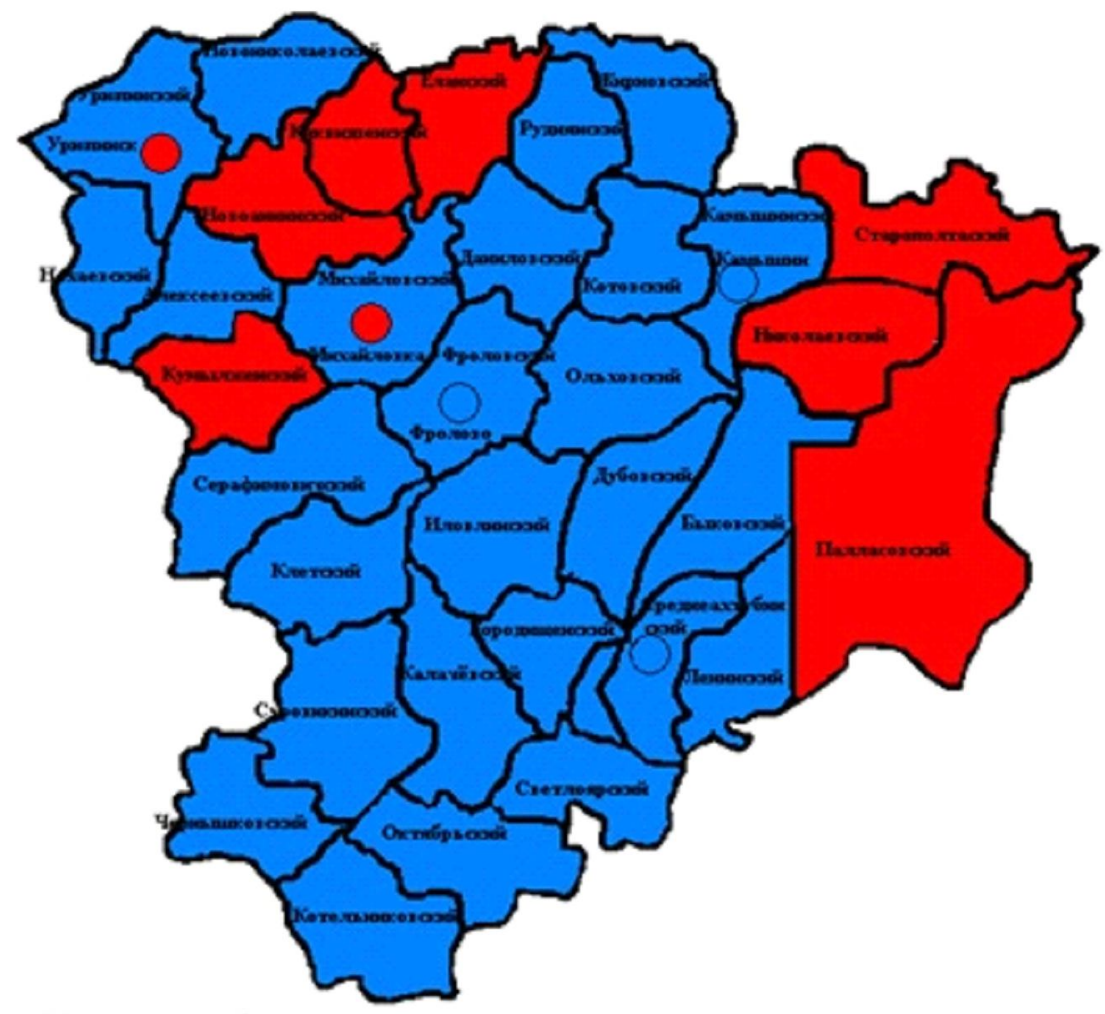

Условные обознатенгя:

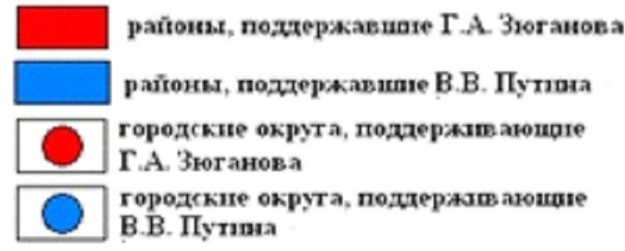

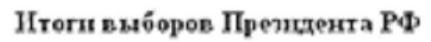
2000 года

в Волгоградской області

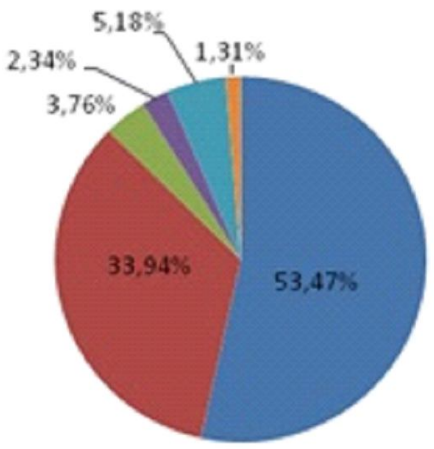

- Путин В.В.

" Зюганов Г.A.

= Явлансий $\Gamma$.A.

- Жирнаноскай В.В.

ш остапьые кандицаты

mpong всех

Рис. 8. Предпочтения электората Волгоградской области в выборах Президента РФ 2000 г.

Fig. 8. Preferences of the electorate of Volgograd region in the presidential elections of 2000 Примечание. Составлено авторами по: [2]. 
В.В. Фесенко, Л.В. Деточенко. Территориальный анализ политических предпочтений населения

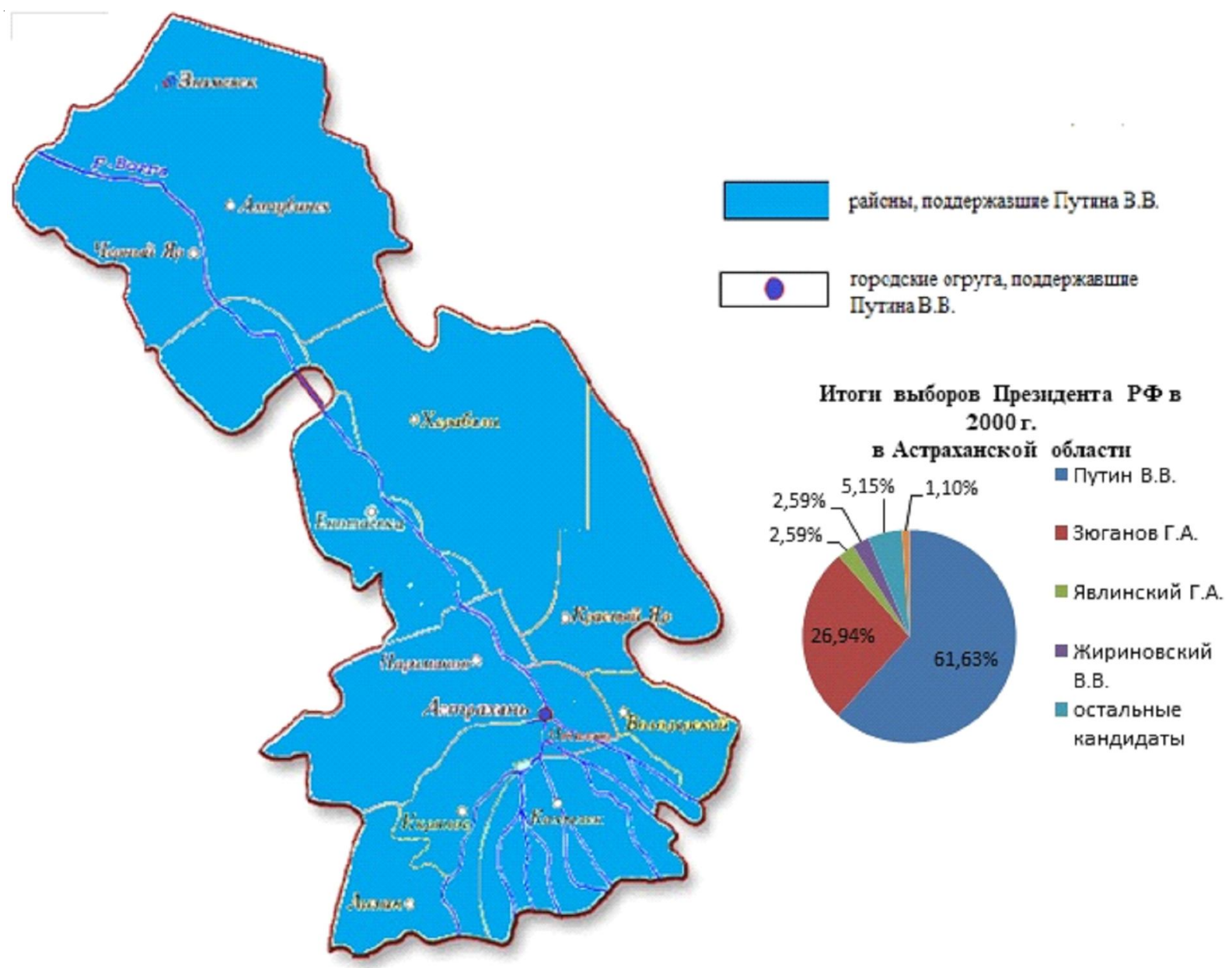

Рис. 9. Предпочтения электората Астраханской области в выборах Президента РФ 2000 г.

Fig. 9. Preferences of the electorate of Astrakhan region in the presidential elections of 2000 Примечание. Составлено авторами по: [1]. 


\section{НАРОДЫ РОССИИ И ЕВРОПЫ: ИСТОРИЯ И ПОЛИТИКА}

Итоги выборов Президента РФ 2004 года

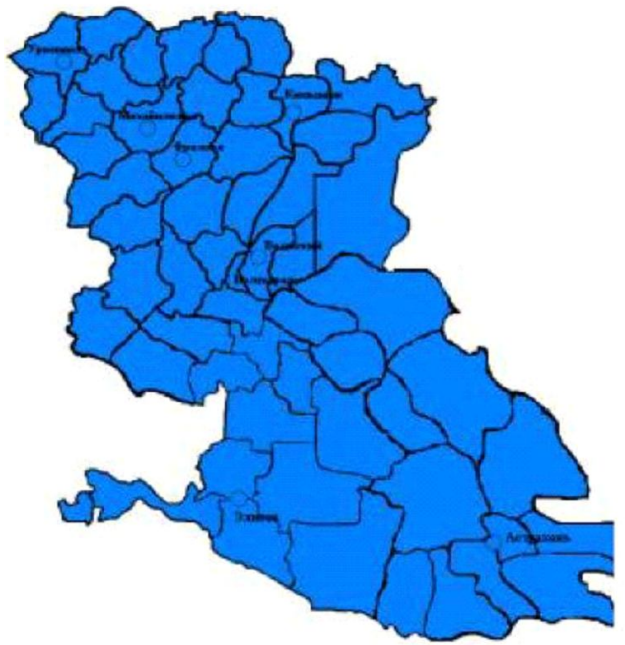

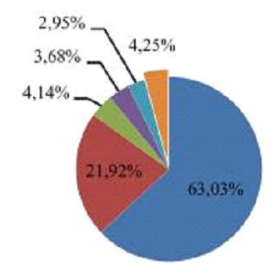

Волгоградская область

Е Путин В.в.

- Хакамада И.М.

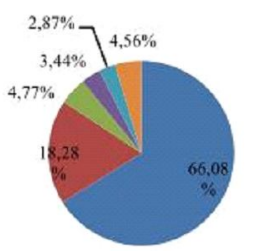

Астраханская область

= Харитонов Н.M

естальные кандидаты

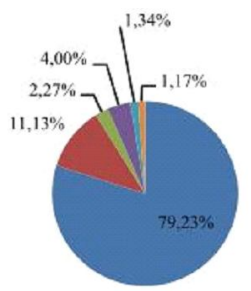

Республика Калмыкия

= Глазьев С.ю. ш потив всех

Итоги выборов Президента РФ 2008 года
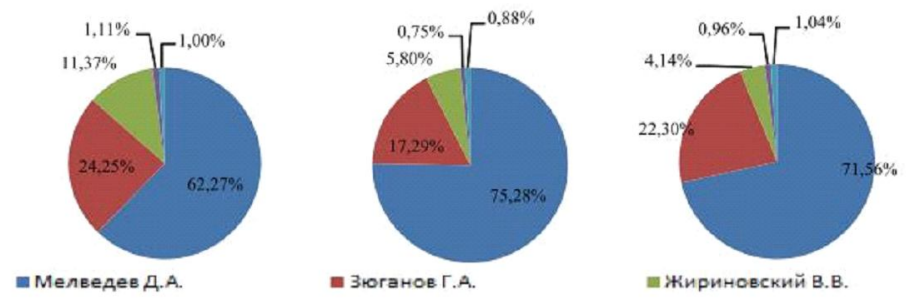

= остальные кандидатты

Итоги выборов Президента РФ 2012 года

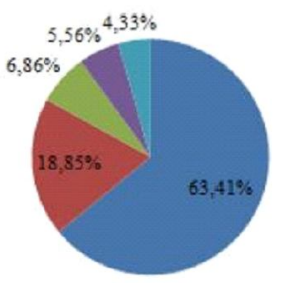

Волгоградская область

путтин В.В.

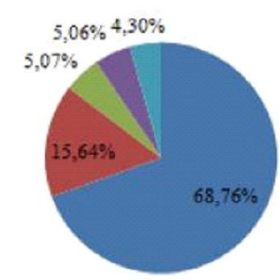

Астраханская об́ласть

- 3 юганов Г.А.

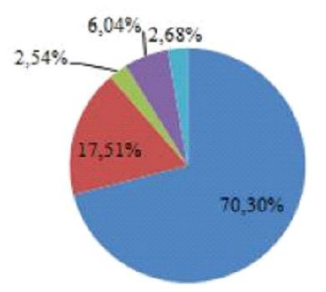

Республика Калмыкня

- Миронов С.M.

Итоги выборов Президента РФ 2018года

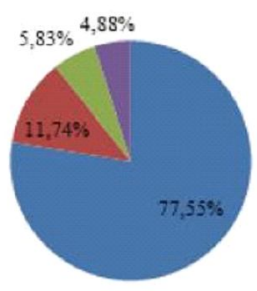

Волгоградская об́ласть

шутин В.В.

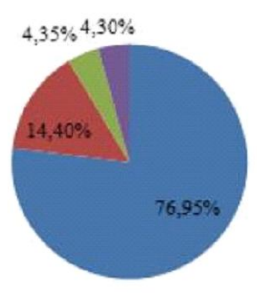

Астраханская область

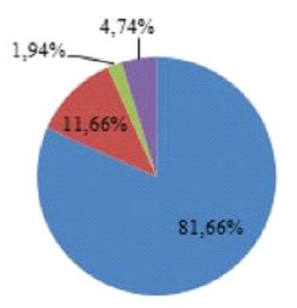

Республика Калмыкия

Рис. 10. Предпочтения электората Нижневолжского мезорегиона ЮФО в выборах Президента РФ 2004-2018 гг.

Fig. 10. Preferences of the electorate of the Lower Volga mesoregion of the Southern Federal District in the presidential elections of 2004-2018

Примечание. Составлено авторами по: [1-4]. 


\section{СПИСОК ЛИТЕРАТУРЫ}

1. Архив выборов и референдумов // Избирательная комиссия Астраханской области. - Электрон. текстовые дан. - Режим доступа: http://www. astrakhan. izbirkom.ru/news/7839/ (дата обращения: 19.04.2019).

2. Архив выборов и референдумов // Избирательная комиссия Волгоградской области. - Электрон. текстовые дан. - Режим доступа: http://www. volgograd.vybory.izbirkom.ru/region/volgograd (дата обращения: 18.04.2019).

3. Архив выборов и референдумов // Избирательная комиссия Республики Калмыкия. - Электрон. текстовые дан. - Режим доступа: http://www. kalmyk.izbirkom.ru/izbirkom/arkhiv-vyborov/index.php (дата обращения: 20.04.2019).

4. Архив федеральных выборов и кампаний референдумов // Центральная избирательная комиссия Российской Федерации. - Электрон. текстовые дан. - Режим доступа: http://www.cikrf.ru/ banners/vib_arhiv/ (дата обращения: 25.04.2019).

5. Дружинин, А. Г. Юг России конца XX - начала XXI в. (экономико-географические аспекты) / А. Г. Дружинин. - Ростов н/Д : Изд-во Рост. ун-та, 2005. $-284 \mathrm{c}$.

6. Стереотипы политического мышления молодежи в контексте реализации стратегии национальной безопасности РФ: опыт регионального исследования / В. Н. Гуляихин, О. Е. Андрющенко, П. П. Фантров, Е. В. Галкина // Вестник Волгоградского государственного университета. Серия 4, История. Регионоведение. Международные отношения. - 2018. - Т. 23, № 2. - C. 186-194. - DOI: https: //doi.org/10.15688/ jvolsu4.2018.2.16

7. Трегубов, Н. А. Факторы голосования: вопросы классификации и анализа / Н. А. Трегубов // Полис. Политические исследования. - 2017. № 3. - C. 119-134. - DOI: https://doi.org/10.17976/ jpps/2017.03.08

8. Туровский, Р. Ф. Политическая география / Р. Ф. Туровский. - М. ; Смоленск : Изд-во СГУ, 1999. $-381 \mathrm{c}$.

\section{REFERENCES}

1. Arkhiv vyborov i referendumov [Archive of Elections and Referenda]. Izbiratelnaya komissiya Astrakhanskoy oblasti [Election Commission of
Astrakhan Region]. URL: http://www.astrakhan. izbirkom.ru/news/7839/ (accessed 19 April 2019).

2. Arkhiv vyborov i referendumov [Archive of Elections and Referenda]. Izbiratelnaya komissiya Volgogradskoy oblasti [Election Commission of Volgograd Region]. URL: http://www.volgograd. vybory.izbirkom.ru/region/volgograd (accessed 18 April 2019).

3. Arkhiv vyborov i referendumov [Archive of Elections and Referenda]. Izbiratelnaya komissiya Respubliki Kalmykiya [Election Commission of the Republic of Kalmykia]. URL: http://www.kalmyk. izbirkom.ru/izbirkom/arkhiv-vyborov/index.php (accessed 20 April 2019).

4. Arkhiv federalnykh vyborov i kampaniy referendumov [Archive of Federal Elections and Referendum Campaigns]. Tsentralnaya izbiratelnaya komissiya Rossiyskoy Federatsii [Central Election Commission of the Russian Federation]. URL: http:// www.cikrf.ru/banners/vib_arhiv/ (accessed 25 April 2019).

5. Druzhinin A.G. Yug Rossii kontsa XXnachala XXI v. (ekonomiko-geograficheskie aspekty) [South of Russia of the Late $20^{\text {th }}$ - Early $21^{\text {st }}$ Century (Economic and Geographical Aspects)]. Rostov-onDon, Izd-vo Rost. un-ta, 2005. 284 p.

6. Gulyaikhin V.N., Andryushchenko O.E., Fantrov P.P., Galkina E.V. Stereotipy politicheskogo myshleniya molodezhi $\mathrm{v}$ kontekste realizatsii strategii natsionalnoy bezopasnosti RF: opyt regionalnogo issledovaniya [The Stereotypes of Political Thinking of Youth in the Context of National Security Strategy of Russia: Experience of Regional Research]. Vestnik Volgogradskogo gosudarstvennogo universiteta. Seriya 4, Istoriya. Regionovedenie. Mezhdunarodnye otnosheniya [Science Journal of Volgograd State University. History. Area Studies. International Relations], 2018, vol. 23, no. 2, pp. 186-194. (in Russian). DOI: https://doi.org/10.15688/jvolsu4.2018.2.16

7. Tregubov N.A. Faktory golosovaniya: voprosy klassifikatsii i analiza [Factors of Electoral Choice: The Classification and Analysis]. Polis. Political Studies, 2017, no. 3, pp. 119-134. (in Russian) DOI: https://doi.org/10.17976/jpps/2017.03.08

8. Turovskiy R.F. Politicheskaya geografiya [Political Geography]. Moscow; Smolensk, Izd-vo SGU, 1999. 381 p. 


\section{НАРОДЫ РОССИИ И ЕВРОПЫ: ИСТОРИЯ И ПОЛИТИКА}

\section{Information about the Authors}

Vladimir V. Fesenko, Associate Professor, Department of Geography and Cartography, Volgograd State University, Prosp. Universitetsky, 100, 400062 Volgograd, Russian Federation, fesenko@volsu.ru, https://orcid.org/0000-0003-3384-5192

Liliya V. Detochenko, Associate Professor, Department of Geography and Geoecology, Volgograd State Socio-Pedagogical University, Prosp. Lenina, 27, 400005 Volgograd, Russian Federation, lillyad@rambler.ru, https://orcid.org/0000-0002-9483-6399

\section{Информация об авторах}

Владимир Владимирович Фесенко, доцент кафедры географии и картографии, Волгоградский государственный университет, просп. Университетский, 100, 400062 г. Волгоград, Российская Федерация, fesenko@volsu.ru, https://orcid.org/0000-0003-3384-5192

Лилия Валерьяновна Деточенко, доцент кафедры географии и геоэкологии, Волгоградский государственный социально-педагогический университет, просп. Ленина, 27, 400005 г. Волгоград, Российская Федерация, lillyad@rambler.ru, https://orcid.org/0000-0002-9483-6399 